\title{
Flavonoids and Phenolic Acids from Oregano: Occurrence, Biological Activity and Health Benefits
}

\author{
Erick P. Gutiérrez-Grijalva ${ }^{1}$ (i), Manuel A. Picos-Salas ${ }^{1}$, Nayely Leyva-López ${ }^{2}$ (i), \\ Marilyn S. Criollo-Mendoza ${ }^{1}$, Gabriela Vazquez-Olivo ${ }^{1}$ (D) and J. Basilio Heredia ${ }^{1, *}$ \\ 1 Laboratorio de Alimentos Funcionales y Nutracéuticos, Centro de Investigación en Alimentación y \\ Desarrollo, AC. Carretera a Eldorado Km 5.5, Col. Campo el Diez, Culiacán CP 80110, Sinaloa, Mexico; \\ erickpaulggrijalva@gmail.com (E.P.G.-G.); manueladrianpi@gmail.com (M.A.P.-S.); \\ marilyn_criollo_12@hotmail.com (M.S.C.-M.); vazquezgabriela18@gmail.com (G.V.-O.) \\ 2 Laboratorio de Nutrición y Planta de Alimentos, CONACYT-Centro de Investigación en Alimentación y \\ Desarrollo, A.C., Av. Sábalo-Cerritos s/n, Mazatlán CP 82100, Sinaloa, Mexico; nayely061005@gmail.com \\ * Correspondence: jbheredia@ciad.mx; Tel.: +52-667-760-5536
}

Received: 11 October 2017; Accepted: 23 December 2017; Published: 26 December 2017

\begin{abstract}
Several herb species classified as oregano have been widely used in folk medicine to alleviate inflammation-related diseases, respiratory and digestive disorders, headaches, rheumatism, diabetes and others. These potential health benefits are partially attributed to the phytochemical compounds in oregano such as flavonoids (FL) and phenolic acids (PA). Flavonoids and phenolic acids are among the most abundant and most studied phytochemicals in oregano species. Epidemiological, in vitro and in vivo experiments have related long-term consumption of dietary FL and PA with a decreased risk of incidence of chronic diseases. The aim of this manuscript is to summarize the latest studies on the identification and distribution of flavonoids and phenolic compounds from oregano species and their potential antioxidant, anti-inflammatory and anti-cancer health benefits.
\end{abstract}

Keywords: oregano; flavonoids; phenolic acids; antioxidant; flavones; flavonols; hydroxycinnamic acids; hydroxybenzoic acids; phytochemicals

\section{Introduction}

It has been stated that oregano is the name used to refer to a numerous variety of plants that share a particular flavor and odor. At least 60 species and 17 genera belonging to diverse botanical families are known as oregano. However, the most relevant families are Verbenaceae and Lamiaceae [1]. Interestingly Franz and Novak [2] discusses this issue and reports a table listing species and family information of the oregano plants. Moreover, in this study we have considered as oregano the species in that list. Oregano has been traditionally used in folk medicine to alleviate conditions such as asthma, bronchitis, coughs, diarrhea, indigestion, stomachache, menstrual disorders, general infections, inflammation-related illnesses and diabetes [3]. The benefits of oregano on human health have been attributed to their phytochemical content $[3,4]$. Phytochemicals are a heterogeneous class of compounds derived from the secondary metabolism of plants, thus most of them do not appear to participate in essential metabolic roles. Research indicates that the main physiological function of phytochemicals is to serve as a plant defense mechanism against plant pathogens, pests, herbivores, UV-light and oxidative stress [5,6]. And their content in plants depends on factors such as cultivar, geographical localization, weather, daylight, temperature, soil conditions, water stress, harvesting time and others [7]. The most important phytochemicals found in oregano are grouped depending on their hydrophilic and hydrophobic properties into two categories: essential oils and phenolic compounds. Although research has often focused on the study of essential oils [8], they represent only one of the 
main groups of phytochemicals found in oregano. Thus, the study of hydrophilic compounds such as phenolic compounds is frequently ignored.

Flavonoids (FL) and phenolic acids (PA) are the main types of phenolic compounds present in oregano [9]. Oregano FL and PA have been studied due to their therapeutic potential, which has been partly attributed to their antioxidant properties $[4,10]$. Flavonoids and phenolic acids are molecules characterized by having at least one aromatic ring with one or more hydroxyl groups attached. FL and PA are compounds with a wide range of structures and can be classified based on the number and arrangement of their carbon atoms in: flavonoids (flavonols, flavones, flavan-3-ols, anthocyanidins, flavanones, isoflavones and others) and non-flavonoids (phenolic acids, hydroxycinnamic acids, hydroxybenzoic acids, stilbenes and others) and they are commonly found conjugated to sugars and organic acids [11-13]. All flavonoids are derived from the aromatic amino acids, phenylalanine and tyrosine and are $\mathrm{C} 15$ compounds arranged in three rings (C6-C3-C6) which are designated as $\mathrm{A}, \mathrm{B}$ and C (Figure 1) [14]. Their structure varies due to the degree and pattern of hydroxylation, prenylation, alkalization or glycosylation reactions that modify the primary molecule [13]. These modifications can alter the water solubility of flavonoids, which can directly affect their bioavailability [15]. Flavones, which are the most abundant flavonoids present in oregano species, are characterized by the presence of a ketone group between C-2 and C-3 and the attachment of the B ring to C-2. Among the most widely distributed flavones in nature are apigenin, luteolin and their derivatives [14]. For further information regarding the physiological function and health effects of flavones we suggest the studies by Jiang et al. [16] and Singh et al. [17]. On the other hand, hydroxycinnamic acids are part of the non-flavonoid phenolics and the main subgroup of phenolic acids distributed in the different oregano species [18]. They are formed with an aromatic ring and a three-carbon chain (C6-C3) (Figure 1) [11]. There are four basic structures: coumaric acid, caffeic acid, ferulic acid and sinapic acid. In nature, they are usually associated with other compounds such as chlorogenic acid, which is the link between caffeic acid and quinic acid [19].<smiles>[R3]c1cc(/C=C/C(=O)O)c([125I])c(Br)c1Br</smiles><smiles>[R9]c1cc(C(=O)O)c(Br)c(Br)c1Br</smiles>

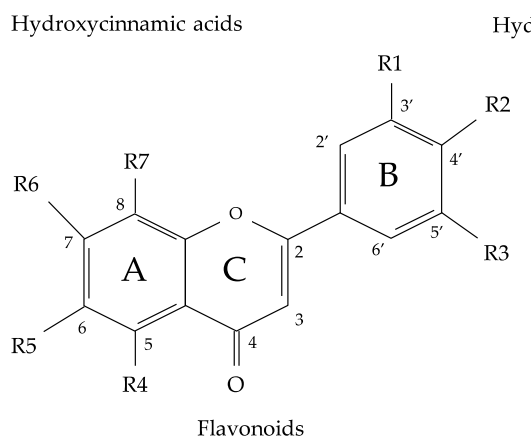

Figure 1. General structure of hydroxycinnamic acids, hydroxybenzoic acids and flavonoids.

\section{Flavonoids and Phenolic Acids Composition of Oregano Species}

With the growing evidence on the biological activity from flavonoids and phenolic acids of oregano species, the identification of these compounds in oregano is important. Reports from different oregano species have shown that flavones are among the most abundant sub-group of FL followed by flavonols (Figure 2), flavanones and flavanols. Among the most common PA in oregano are: hydroxycinnamic acid and hydroxybenzoic acid derivatives and other phenolics [9]. The major individual FL and PA that 
have been identified in oregano species are rosmarinic acid, apigenin, luteolin, quercetin, scutellarein and their derivatives $[4,9]$.<smiles>COc1cc2oc(-c3ccc(O)cc3)cc(=O)c2c(O)c1O</smiles><smiles>O=C1C=C(c2ccc(O)cc2)O[C@@H]2CC(OC3OC(CO)C(O)C(O)C3O)=CC(O)=C12</smiles><smiles>CCC1OC(Oc2cc(O)c3c(=O)cc(-c4ccc(O)c(O)c4)oc3c2)C(O)C(O)C1O</smiles><smiles>O=C1C=C(c2ccc(O)c(O)c2)O[C@@H]2CC(OC3OC(C(=O)O)C(O)C(O)C3O)=CC(O)=C12</smiles>

Figure 2. Chemical structure of common flavones commonly found in oregano species. (a) apigenin, (b) luteolin, (c) scutellarein, (d) apigenin-7-O-glucoside, (e) luteolin-7-O-glucoside, (f) luteolin-7-O-glucuronide. Structures from Phenol-Explorer Database, Version 3.6 [20].

The content and distribution of FL and PA in oregano can vary depending on the cultivar, geographical and environmental factors aforementioned. It has been indicated that the flavonoid and phenolic acids profile of each oregano can be used to differentiate between oregano chemotypes within the same species. For instance, Timóteo et al. [21] reported that the flavonoids tricin-7-O-diglucuronide, chrysoeriol-7-O-diglucuronide and luteolin-7-O-glucuronide can be used to discriminate between three Brazilian chemotypes of Lippia alba. Similarly, Barbosa et al. [22] reported that two flavonoids, namely 5,5" -dihydroxy- $6,4^{\prime}, 6^{\prime \prime}, 3^{\prime \prime}, 4^{\prime \prime \prime}$-pentamethoxy-[ $\left.\mathrm{C}_{7}-\mathrm{O}-\mathrm{C}_{7}{ }^{\prime \prime}\right]$-biflavone and $4^{\prime}, 4,5,5^{\prime \prime}$-tetrahycroxy-6, $6^{\prime \prime}, 3^{\prime \prime \prime}$-trimethoxy- $\left[\mathrm{C}_{7}-\mathrm{O}-\mathrm{C}_{7}{ }^{\prime \prime}\right]$-biflavone, can be used to identify the limonene-carvone chemotype of Lippia alba. Likewise, the levels of rosmarinic acid have been reported to vary between the chemotypes within the species of $O$. vulgare ssp. hirtum, $O$. vulgare and O. syriacum [23]. Additionally, the FL and PA content of oregano species can vary depending on the vegetative stage of the plant. For instance, Baâtour et al. [24] suggested that during the late vegetative states of $O$. majorana $\mathrm{L}$., there is a higher content of trans-2 hydroxinnamic, gallic and quercetin-3-galactoside, which makes it the best stage for harvesting O. majorana plants.

It can also be observed that oregano genotypes from the same species but from different places of origin can vary in their FL and PA composition, as is the case with the species Lippia graveolens, Lippia alba, O. majorana, O. vulgare and other oregano species. To illustrate, a recent study by Leyva-López et al. [4] reported 5 flavonoids in Lippia graveolens collected in Mexico, which are mainly flavones, namely quercetin-O-hexoside, scutellarein-7-O-hexoside, phloridzin, a trihydroxy-methoxyflavone derivative and 6-O-methylscutellarein. Whilst L. graveolens collected from Colombia reported by Stashenko et al. [25] had a different flavonoid profile with only 4 flavonoids, namely apigenin, luteolin, naringenin and quercetin. In contrast, $O$. vulgare collected from two different countries, China and Greece, showed a highly similar profile in their FL and PA content [26,27].

A summary of the major flavonoids and phenolic acids found in oregano species can be found in Table 1. 
Table 1. Principal components of flavonoids and phenolic compounds of different oregano species.

\begin{tabular}{|c|c|c|c|c|}
\hline Oregano Species & Origin & Extraction Solvent & Flavonoids and Phenolic Acids Constituents & Reference \\
\hline Hedeoma patens & Mexico & $\begin{array}{l}\text { Methanol/acetone/water } \\
(50: 40: 10)\end{array}$ & $\begin{array}{l}\text { 3-O-caffeoylquinic acid, luteolin-7-O-glucuronide, scutellarein-7-O-hexoside, salvianolic } \\
\text { acid A }\end{array}$ & {$[4]$} \\
\hline $\begin{array}{l}\text { Lippia alba (Mill.) } \\
\text { N. E. Brown }\end{array}$ & Brazil & Methanol 62.5\% & $\begin{array}{l}\text { Apigenin-7-O-diglucuronide, chrysoeriol-7-O-diglucuronide, } \\
\text { luteolin-7-O-glucuronide, tricin-7-O-diglucuronide, tricin-7-O-glucuronide }\end{array}$ & [25] \\
\hline $\begin{array}{l}\text { Lippia alba (Mill.) } \\
\text { N. E. Brown }\end{array}$ & France & Methanol/hydromethanol & Luteolin-7-diglucuronide, verbascoside, chlorogenic acid & {$[28]$} \\
\hline $\begin{array}{l}\text { Lippia alba (Mill.) } \\
\text { N.E. Brown }\end{array}$ & Brazil & Chloroform & $\begin{array}{l}5,5^{\prime \prime} \text {-dihydroxy- } 6,4^{\prime}, 6^{\prime \prime}, 3^{\prime \prime \prime}, 4^{\prime \prime \prime} \text {-pentamethoxy- }\left[\mathrm{C}_{7}-\mathrm{O}-\mathrm{C}_{7}{ }^{\prime \prime}\right] \text {-biflavone, } \\
4^{\prime}, 4,5,5^{\prime \prime} \text {-tetrahydroxy- } 6,6^{\prime \prime}, 3^{\prime \prime \prime} \text {-trimethoxy- }\left[\mathrm{C}_{7}-\mathrm{O}-\mathrm{C}_{7}{ }^{\prime \prime}\right] \text {-biflavone }\end{array}$ & {$[22]$} \\
\hline Lippia citriodora & Germany & Water & Verbasoside, luteolin-7-diglucuronide, apigenin-7-diglucuronide & [29] \\
\hline Lippia graveolens & Mexico & $\begin{array}{l}\text { Methanol/acetone/water } \\
(50: 40: 10)\end{array}$ & $\begin{array}{l}\text { Quercetin } O \text {-hexoside, scutellarein 7-O-hexoside, phloridzin, } \\
\text { trihydroxy-methoxyflavone derivative, 6-O-methylscutellarein }\end{array}$ & [4] \\
\hline Lippia graveolens & $\mathrm{NR}^{1}$ & Methanol 70\% & $\begin{array}{l}\text { 6-Hydroxyluteolin 7-O-hexoside, pentaflavanone-B hexoside-1, pentaflavanone-B } \\
\text { hexoside-2, scutellarein 7-O-hexoside, luteolin 7-O-glucoside, taxifolin, } \\
\text { 6-hydroxyluteolin 7-O-rhamnoside, 6-hydroxyluteolin, 3-hydroxyphloretin } \\
\text { 6'-O-hexoside, apigenin 7-O-glucoside, phloridzin, scutellarein, eriodictyol, luteolin, } \\
\text { quercetin, naringenin, 6-methylscutellarein, 6,7-dimethylscutellarein, sakuranetin, } \\
\text { pinocembrin, galangin, methylgalangin }\end{array}$ & [9] \\
\hline Lippia graveolens & USA & Methanol 100\% & Eriodictyol, naringenin, hispidulin, cirsimaritin & [30] \\
\hline Lippia micromera & Colombia & Methanol/hydromethanol & Naringenin, apigenin & [28] \\
\hline Lippia origanoides & Colombia & Methanol 62.5\% & Quercetin, naringenina, luteolin, pinocembrin & [25] \\
\hline Lippia palmeri & Mexico & $\begin{array}{l}\text { Methanol/acetone/water } \\
(50: 40: 10)\end{array}$ & $\begin{array}{l}\text { Quercetin-O-hexoside, luteolin 7-O-glucuronide-3'-O-glucoside, scutellarein } \\
\text { 7-O-hexoside, trihydroxy-methoxyflavone derivative }\end{array}$ & [4] \\
\hline $\begin{array}{l}\text { Majorana hortensis } \\
\text { Moench. }\end{array}$ & Poland & Water & Caffeic acid, lithospermic acid, rosmarinic acid & [31] \\
\hline O. acutidens & Turkey & Water & Gallic acid, caffeic acid, 4-hydroxybenzaldehyde, $p$-coumaric acid, rosmarinic acid & [32] \\
\hline
\end{tabular}


Table 1. Cont.

\begin{tabular}{|c|c|c|c|c|}
\hline Oregano Species & Origin & Extraction Solvent & Flavonoids and Phenolic Acids Constituents & Reference \\
\hline O. dictamus & Greece & Methanol $62.5 \% /$ BHT & $\begin{array}{l}\text { Vanillic acid, protocatechuic acid, syringic acid, gallic acid, cinnamic acid, o-coumaric } \\
\text { acid, } p \text {-coumaric acid, caffeic acid, chlorogenic acid, rosmarinic acid, chrysin, } \\
\text { epicatechin, naringenin, catechin, genistein, quercetin }\end{array}$ & [33] \\
\hline O. dictamus & Greece & Water & $\begin{array}{l}\text { Chlorogenic acid, rutin, luteolin-7-O-glucoside, apigenin-7-O-glucoisde, rosmarinic } \\
\text { acid, luteolin }\end{array}$ & {$[34]$} \\
\hline O. indercedens & Greece & Methanol & Caffeic acid, rosmarinic acid & [35] \\
\hline O. majoram L. & Germany & $\begin{array}{l}\text { Methanol } 60 \% / \text { Formic acid } \\
1 \%\end{array}$ & $\begin{array}{l}\text { Apigenin-6,8-di-C-glucoside, luteolin-7'-O-glucuronide, rosmarinic acid, } \\
\text { apigenin-glucuronide, lithospermic acid A isomer a, salvianolic acid B, apigenin }\end{array}$ & [36] \\
\hline \multirow{5}{*}{ O. majoram L. } & Tunisia & Methanol & $\begin{array}{l}\text { Dihydroxybenzoic acid hexose, syringic acid, vanillic acid, dihydroxybenzoic acid, } \\
\text { p-coumaric acid, chlorogenic acid, salvianolic acid I, caffeoyl-arbutin, rosmarinic acid, } \\
\text { gallocatechin isomer 1, gallocatechin isomer 2,3-O-methyl-catechin, } \\
\text { luteolin-6,8-C-dihexose, apigenin-6,8-di-C-hexoside, isoorientin, orientin, isovitexin, } \\
\text { kaempferol-O-sumbubioside, kaempferol-O-glucuronide, luteolin-O-glycoside, } \\
\text { diosmin, apigenin-O-glucuronide, acacetin rutinoside, luteolin, apigenin, taxifolin, } \\
\text { taxifolin methyl ether isomer 1, taxifolin methyl ether isomer 2, dihydrokaempferide, } \\
\text { hesperidin, eriodictyol, sakuranetin, O-methy-quercetin, dimethyl myriceitn, quercetin } \\
\text { dimethyl ether, jaceidin isomer 1, jaceidin isomer } 2\end{array}$ & [37] \\
\hline & Greece & Water & $\begin{array}{l}\text { Vanillic acid, protocatechuic acid, syringic acid, gallic acid, cinnamic acid, o-coumaric } \\
\text { acid, } p \text {-coumaric acid, ferulic acid, caffeic acid, sinapic acid, rosmarinic acid, chrysin, } \\
\text { epicatechin, naringenin, catechin, kaempferol, quercetin }\end{array}$ & [34] \\
\hline & Poland & Methanol & $\begin{array}{l}\text { Protocatechuic acid, } p \text {-hydroxybenzoic acid, gentisic acid, chlorogenic acid, } \\
\text { syringic acid }\end{array}$ & [38] \\
\hline & Turkey & Methanol 80\% & $\begin{array}{l}\text { Caffeic acid glucoside, epigallocatechin, arbutin, luteolin ruitinoside, luteolin } \\
\text { glucuronide, rosmarinic acid, dihydroquercetin, dihydroluteolin, apigenin, quercetin, } \\
\text { quercetin arabinoside, luteolin-7-O-glucoside gallocatechin derivative }\end{array}$ & [39] \\
\hline & Germany & Methanol 50\% & $\begin{array}{l}\text { Luteolin-6,8-di-C-glucoside, apigenin-6,8-di-C-glucoside, luteolin-glucuronide, } \\
\text { rosmarinic acid, apigenin-glucuronide, lithospermic acid, apigenin }\end{array}$ & {$[40]$} \\
\hline
\end{tabular}


Table 1. Cont

\begin{tabular}{|c|c|c|c|c|}
\hline Oregano Species & Origin & Extraction Solvent & Flavonoids and Phenolic Acids Constituents & Reference \\
\hline \multirow{6}{*}{ O. majoram L. } & USA & Methanol 80\% & $\begin{array}{l}\text { Eriodictyol 6,8-di-C-glucoside, eriodictyol 7-O-glucoside, apigenin 6,8-di-C-glucoside, } \\
\text { luteolin 7,7'-di-O-glucuronide, luteolin 7-O-glucuronide-3'-O-glucoside, apigenin } \\
\text { 7-O-diglucuronide, luteolin 7-O-glucuronide, luteolin 7-O-glucuronide, luteolin } \\
\text { 7-O-glucoside, apigenin 7-O-glucoside, apigenin 7-O-glucuronide, rosmarinic acid }\end{array}$ & {$[41]$} \\
\hline & Turkey & Water & $\begin{array}{l}\text { Gallic acid, caffeic acid, } p \text {-coumaric acid, rosmarinic acid, chicoric acid, } \\
\text { apigenin-7-glucoside, quercetin, kaempferol }\end{array}$ & [32] \\
\hline & Italy & $\begin{array}{l}\text { Cascade extraction with } \\
\text { ethyl acetate and ethanol }\end{array}$ & $\begin{array}{l}\text { Eriodictyol 7-O-rutinoside, aromadendrin, eriodictyol, naringenin, luteolin, sorbifolin, } \\
\text { cirsiliol, apigenin, cirsilineol, cirsimaritin, xanthomicrol, caffeic acid, rosmarinic acid }\end{array}$ & [42] \\
\hline & Greece & $\begin{array}{l}\text { Cascade extraction with } \\
\text { hexane and ethyl acetate }\end{array}$ & $\begin{array}{l}\text { Salvianolic acid } \mathrm{H} \text {, salvianolic acid B, rosmarinic acid, salvianolic acid C, eriodictyol, } \\
\text { naringenin }\end{array}$ & [43] \\
\hline & Finland & Methanol 40\% & $\begin{array}{l}\text { Calleryanin 3,4-dihydroxybenzoate, gastrodin 3,4-dihydroxybenzoate, calleryanin } \\
\text { 3-hydroxy,4-methoxybenzoate }\end{array}$ & {$[44]$} \\
\hline & Portugal & Methanol 80\% & $\begin{array}{l}\text { Gallic acid, 3,4-dihydroxybenzoic acid, (+)-catechin, caffeic acid, (-)-epicatechin, } \\
\text { rosmarinic acid }\end{array}$ & [10] \\
\hline Oregano $^{2}$ & Turkey & Methanol 80\% & $\begin{array}{l}\text { Gallic acid, syringic acid, vanillic acid, protocatechuic acid, chlorogenic acid, } p \text {-coumaric } \\
\text { acid, quercetin-3-O-hexoside, luteolin-7-O-glucoside, ferulic acid, phloridzin, } \\
\text { dicaffeoylquinic acid, apigenin-7-O-rutinoside, rutin, apigenin-7-O-glucoside, } \\
\text { rosmarinic acid, luteolin-3-O-glucuronide, luteolin-7-O-rutinoside, quercetin, apigenin, } \\
4^{\prime} \text {-methoxyapigenin, 6,7-dimethoxyscutellarein, luteolin }\end{array}$ & [45] \\
\hline $\begin{array}{l}\text { Poliomintha } \\
\text { longiflora }\end{array}$ & $\mathrm{NR}^{1}$ & Phosphate buffer & Vanillic acid, caffeic acid, luteolin, rosmarinic acid, hispidulin & [46] \\
\hline
\end{tabular}




\section{Physiological Functions of Flavonoids and Phenolic Acids from Oregano Species}

Flavonoids and phenolic acids are accumulated in plant tissues (such as leaves, flowers, stems and roots) as a response to biotic and abiotic stress like pathogen and insect attack, UV radiation and wounding $[13,47]$. Phenolic compounds help plants survive and adapt to environmental disturbances through various physiological functions. Phenolic acids such as hydroxycinnamic acid derivatives serve as precursor molecules for the stilbenes, chalcones, flavonoids, lignans and anthocyanins [48]. These compounds are present in most tissues as conjugates (esters of carboxylic acids or sterols, amides of amino acids or amines, glycosides of mono or disaccharides) or insoluble-bound (attached to the structural components of the plant cell wall); and are rarely found in free form (monomers or dimers) $[18,49]$.

On the other hand, flavonoids have been reported to play a variety of roles in plants, such as UV protection, pigmentation, growth regulation, stimulation of nitrogen-fixing nodules and disease resistance $[11,50]$. Flavonoids have the ability to absorb UV-wavelength; this ability depends on the molecular structure and the nature of substitution on different rings of their molecule. For instance, dihydroxy B ring substituted flavonoids have a better antioxidant capacity, while their monohydroxy B ring substituted analogue have greater capacity to absorb UV wavelengths [50]. The flavones orientin and luteolin are found in high levels in plants exposed to high levels of solar UV-B radiation [51]. Moreover, flavonoids are produced in the cytosol of cells and are present in high concentrations in the epidermis of leaves [52]. Besides, flavonoids may regulate auxin movement and catabolism. For instance, they modulate different phenotypes and morphoanatomical features of plants, because of their ability to create auxin gradients [50]. Furthermore, flavonoids play a role in the protection of plants against plant feeding insects and herbivores; since their presence can alter the palatability of plants and reduce their nutritive value, decrease digestibility or even act as toxins [53]. Additionally, quercetin 3-O-rutinoside (rutin) has been reported to enhance membrane rigidity and protect the membrane from oxidative damage caused by lipid peroxidation [50].

For a more detailed description of the chemistry and biological functions of flavonoids in plants, please refer to the review in the literature Samanta et al. [52].

\section{Health Benefits of Flavonoids and Phenolic Compounds from Oregano Species}

Epidemiological, in vitro and in vivo evidence has associated regular dietary intake of FL and PA with lower incidence of chronic diseases [54,55]. Interestingly, the flavonoids and phenolic acids that have been identified in oregano species have exhibited antioxidant, anti-inflammatory and anti-cancer properties [10,56,57]. Interestingly, some in vitro, in silico and in vivo studies have proposed a structure-activity relationship of flavonoids and phenolic acids with their biological properties [58-60]. For instance, Ambriz-Pérez et al. [58] summarized the following structure-anti-inflammatory activity relationship of flavonoids:

- A planar ring system in the flavonoid molecule is needed for anti-inflammatory activity

- Hydroxyl groups in B ring and at C5 and C7 of A ring are necessary for anti-inflammatory activity

- The flavones and flavonoles having a hydroxyl group at $4^{\prime}$ position of B ring show higher anti-inflammatory activity

- The methylation of the hydroxyl groups at 3,5 or $4^{\prime}$ positions improves activity

- The methylation of the 3-hydroxyl group reduces cytotoxicity

- Flavones exhibited higher activities than isoflavones, flavonoles and flavanones

- The 5, 6, 7-trihydroxyflavone core structure improves activity

- Aglycones are more bioactive than glycosides

Furthermore, in accordance with the aforementioned, some sub-classes of flavonoids that are present in oregano species, have been related with higher activity towards certain diseases. For example, flavones have been linked with many pharmacological properties such as neuroprotective, 
anti-inflammatory, antioxidant, anti-asthmatic, anti-ulcer, decreased risk of cardiovascular diseases, anti-diabetic, anti-cancer, etc. [17,61-63]. Flavonols, for instance, have been associated with decreased risk of cardiovascular diseases [64]. Hydroxycinnamic acid derivatives have been linked with anti-diabetic, antioxidant and anti-cancer properties [65,66]. In the following sub-sections, we will briefly discuss studies regarding the antioxidant, anti-inflammatory and anti-cancer properties of oregano.

\subsection{Antioxidant Properties of $F L$ and $P A$ from Oregano}

Flavonoids and phenolic acids from oregano have been reported with antioxidant properties [4]. These compounds can be extracted using different polar solvents like water, methanol and ethanol to obtain antioxidant-rich extracts. The antioxidant capacity of a sample is usually measured by different methods typically classified in two groups: hydrogen atom transfer (HAT) and electron transfer (ET). For instance, the oxygen radical absorbance assay (ORAC) is among the most common HAT assay used. On the other hand, the most commonly used ET methods are: the inhibition of the 1,1'-diphenyl-2-picrylhydrazyl radical (DPPH), the Trolox equivalent antioxidant capacity (TEAC) method/ABTS radical cation decolorization assay (also known as ABTS assay), the ferric reducing-antioxidant power assay (FRAP), the cupric ion reducing antioxidant capacity method (CUPRAC) and total phenolic content assay. Interestingly, DPPH and ABTS can also act like HAT $[67,68]$. Table 2 summarizes studies regarding antioxidant capacity in oregano species.

It has been reported that the antioxidant capacity of extracts from different oregano species is somewhat dependent on the solvents used during their extraction, which has been correlated with the FL and PA yielding during the process. A different study showed that the methanolic extract of the stem has strong antioxidant capacity against the DPPH radical ( $96 \%$ at $200 \mathrm{ppm})$, superoxide anion radical scavenging ( $61 \%$ at $250 \mathrm{ppm})$ and TAC $(634 \mu \mathrm{M} \mathrm{AAE} / \mathrm{g}$ of extract); which is attributed to their phenolic content such as rosmarinic acid, caffeic acid, rutin, gallic acid, quercetin and $p$-coumaric acid as reported by HPLC analysis [69]. Moreover, Singh et al. [70] studied various leaf extracts from Eryngium foetidum, interestingly the aqueous extract had the highest phenolic content (256 $\mathrm{mg}$ gallic acid equivalents(GAE)/100 $\mathrm{g}$ fresh weight); furthermore, the methanolic extract was characterized by the presence of gallic, protocatechuic, syringic, $p$-coumaric, ferulic and sinapic acids.

The antioxidant capacity of oregano can also be affected by the cooking process. For instance, the effect of decoction and infusion on aqueous extracts of the leaves from Lippia alba has been studied by Timóteo et al. [21], they analyzed three chemotypes of Lippia alba and reported the presence of flavonoids of the class of flavones, especially mono and di-glucuronides of apigenin, luteolin and tricin. The authors noted that decoction samples with higher total phenolics content exhibited higher antioxidant activities (DPPH) than infusions, indicating that longer brewing time is better in the extraction of these compounds. Moreover, it was suggested that the presence of luteolin and luteolin-7-O-glucuronide in some chemotypes could improve the antioxidant capacity of Lippia alba. Aqueous extracts from Lippia graveolens (also known as Mexican oregano) have been studied for their antioxidant properties. For example, the oil free methanolic extract of L. graveolens showed a total phenolic content ranged from 211 to $270 \mathrm{mg} \mathrm{GAE} / \mathrm{g}$ dried extract, where rosmarinic acid and naringenin were identified; meanwhile, in accordance with the TPC, the inhibition of the DPPH radical $\left(\mathrm{IC}_{50}=152-207 \mu \mathrm{g} / \mathrm{mL}\right.$ ) was positively correlated to higher TPC [71]. However, another methanolic extract did not show the presence of rosmarinic acid but the flavonoids eriodictyol, naringenin, hispidulin and cirsimaritin were identified and, similarly to other studies, there was a positive correlation between the TPC and the antioxidant capacity by ORAC assay, around 5-9 mmol Trolox equivalents (TE)/mg of dry weight extract (DWE) [30].

Similarly, Lagouri and Alexandri [72] found a positive correlation between the TPC and antioxidant capacities by DPPH and FRAP of the leaves sequentially extracted with hexane, acetone and methanol, along with their infusion; they showed that the methanolic extract had higher DPPH value and the infusion higher TPC and FRAP value. Moreover, Kaliora et al. [34] observed a positive 
correlation between antiradical activity and quercetin protocatechuic acid, gallic acid, epicatechin, catechin, kaempferol and chlorogenic acid, found on the infusion of leaves and flowers.

Regarding Origanum glandulosum (syn. Origanum compactum), Béjaoui et al. [73] measured the antioxidant capacity of the methanolic extract, presenting an $\mathrm{IC}_{50}$ value of $0.6 \mathrm{mg} / \mathrm{mL}$ for $\mathrm{DPPH}$, attributed principally to the presence of caffeic acid, which has been reported as a potent antioxidant [74]. Another widely studied oregano species regarding antioxidant capacity is Origanum majorana, characterized by the high content of rosmarinic acid. The antioxidant capacity of the microwave assisted methanolic extract from the aerial parts of O. majorana was analyzed by the CUPRAC, DPPH and TPC methods, showing high values attributed to the elevated content of rosmarinic acid, along with apigenin, caffeic acid and rutin [75]. Similarly, Elansary and Mahmoud [76] reported that rosmarinic acid and caffeic acid were the main compounds on the infusion and methanolic extract of the leaves from Origanum majorana, were the last one showed better antioxidant capacity by $\mathrm{DPPH}, \beta$-carotene bleaching and TPC. Other flavonoids that have been found in methanolic extracts of O. majorana with correlation with TPC and ORAC values are eriodictyol and naringenin [30]. Similarly, rosmarinic acid was found to be the phenolic acid that provides the strongest antioxidant activity by FRAP and DPPH on hydromethanolic extract from Origanum majorana [39]. On the other hand, Vallverdú-Queralt et al. [77] did not find the presence of rosmarinic acid in the hydroethanolic extract of Origanum majorana, nevertheless protocatechuic acid, syringic acid and caffeic were the main compounds and the TPC exhibited a positive correlation with the DPPH and ABTS assays. Kogiannou et al. [26] reported relatively low TPC ( $38 \mathrm{mg}$ GAE/ $200 \mathrm{~mL}$ ) on the infusion of the leaves and flowers from Origanum microphyllum, with caffeic acid, syringic acid and naringenin as the main phenolics. Moreover, the antioxidant capacity was attributed to this content of phenolics, especially to caffeic acid, by FRAP assay.

Greek oregano (Origanum vulgare) is the most recognized herb as oregano around the world, generally reporting elevated content of rosmarinic acid. Yan et al. [78] analyzed the hydro-methanolic extract of the leaves from O. vulgare by TPC and ORAC, with results of 79-147 mg GAE/g DW and 1.59-3.39 mmol TE/g DW, respectively; but no correlation was found between the rosmarinic acid content and the antioxidant capacity measured by ORAC, which may indicate that other compounds are acting as antioxidant agents. In contrast, Gonçalves et al. [10] partially attributed the high antioxidant capacity (DPPH, ABTS and FRAP) of the same kind of extract to the large quantity of rosmarinic acid $(23.53 \mathrm{mg} / \mathrm{g}$ of dry extract) and the presence of other active compounds like (-)-epicatechin. A study by Koldaş et al. [32] in O. vulgare associated the presence rosmarinic, chicoric and caffeic acid with the antioxidant capacity of samples. Furthermore, eriodictyol and naringenin were also found in the methanolic extract of $O$. vulgare leaves, which exhibited high TPC $(430 \mu \mathrm{g}$ of $\mathrm{GAE} / \mathrm{mg}$ of DWE) and a positive correlation with the ORAC value ( 11 $\mathrm{mmol} \mathrm{TE} / \mathrm{mg}$ DWE) [30]. Likewise, the flavonoids luteolin-7-O-glucoside and apigenin-7-O-glucoside were obtained using accelerated solvent extraction with methanol, presenting a significant positive correlation between the TPC and the FRAP value [79]. Moreover, Balkan et al. [80] found a correlation between the TPC and DPPH scavenging activity with the presence of eriodictyol, apigenin and caffeic acid in the aqueous extract of $O$. vulgare.

For Thymbra capitata, the ethyl acetate extracts of aerial parts exhibited higher TPC, probably related to the higher content of taxifolin di-O-glucoside; whereas, the ethanolic extract was more efficient on the superoxide scavenging activity assay, the effect attributed to the higher content of rosmarinic acid in the extract [81].

As it can be seen, the polarity of the solvents used to extract FL and PA of interest from oregano can affect the yield and profile of compounds obtained, thus affecting their antioxidant capacity. 
Table 2. A summary of the antioxidant capacity of flavonoids and phenolic acids of different oregano species.

\begin{tabular}{|c|c|c|c|c|c|}
\hline Oregano Species & Extract & Compounds & Plant Part & Antioxidant Assay & Reference \\
\hline Coleus aromaticus & Methanol & $\begin{array}{l}\text { Rosmarinic, caffeic, } p \text {-coumaric and gallic acids; } \\
\text { quercetin and rutin }\end{array}$ & Stem & DPPH, superoxide, TAC & [69] \\
\hline Eryngium foetidum & Aqueous, methanol & $\begin{array}{l}\text { Gallic, protocatechuic, syringic, } p \text {-coumaric, ferulic } \\
\text { and sinapic acids }\end{array}$ & Leaves & TPC, DPPH & [70] \\
\hline Lippia alba & Aqueous & $\begin{array}{l}\text { Apigenin-7-O-diglucuronide, } \\
\text { chrysoeriol-7-O-diglucuronide, } \\
\text { tricin-7-O-diglucuronide, luteolin-7-O-glucuronide }\end{array}$ & Leaves & TPC, DPPH & [21] \\
\hline \multirow{2}{*}{ Lippia graveolens } & Methanol & Rosmarinic acid, naringenin & Aerial parts & TPC, DPPH & [71] \\
\hline & Methanol & Eriodictyol, naringenin, hispidulin, cirsimaritin & $\begin{array}{l}\text { Leaves, } \\
\text { commercial herbs }\end{array}$ & TPC, ORAC & [30] \\
\hline \multirow[t]{2}{*}{ Origanum dictamnus } & $\begin{array}{l}\text { Sequentially with } \\
\text { hexane, acetone and } \\
\text { methanol; Aqueous }\end{array}$ & $\begin{array}{l}\text { Methanolic: gallic, caffeic, ferulic and rosmarinic } \\
\text { acids. Aqueous: gallic, caffeic, protocatechuic and } \\
\text { rosmarinic acids }\end{array}$ & Leaves & TPC, DPPH, FRAP & [72] \\
\hline & Aqueous & $\begin{array}{l}\text { Rosmarinic, caffeic and vanillic acids, epicatechin, } \\
\text { catechin, genistein }\end{array}$ & $\begin{array}{l}\text { Leaves and } \\
\text { flowers }\end{array}$ & TPC, DPPH, FRAP & [34] \\
\hline Origanum glandulosum & $\begin{array}{l}\text { Methanol, previously } \\
\text { deffated with n-hexane }\end{array}$ & Caffeic acid, luteolin glucoside & Not specified & DPPH, FRAP & [73] \\
\hline \multirow{5}{*}{ Origanum majorana } & Methanol microwave-assisted & Rosmarinic and caffeic acid, apigenin, rutin & Aerial parts & TPC, DPPH, CUPRAC & [75] \\
\hline & Aqueous, methanol & Rosmarinic and caffeic acids & Leaves & $\begin{array}{l}\text { TPC, DPPH, } \beta \text {-carotene } \\
\text { bleaching }\end{array}$ & [76] \\
\hline & Methanol & $\begin{array}{l}\text { Rosmarinic acid, eriodictyol, naringenin, hispidulin, } \\
\text { cirsimaritin }\end{array}$ & $\begin{array}{l}\text { Leaves, } \\
\text { commercial herbs }\end{array}$ & TPC, ORAC & [30] \\
\hline & Methanol & Rosmarinic acid, epigallocatechin, quercetin, apigenin & Not specified & DPPH, FRAP & [39] \\
\hline & Ethanol & $\begin{array}{l}\text { Chlorogenic, ferulic, } p \text {-coumaric, } p \text {-hydroxybenzoic, } \\
\text { protocatechuic, rosmarinic and syringic acids, } \\
\text { quercetin }\end{array}$ & Not specified & TPC, DPPH, ABTS & [77] \\
\hline
\end{tabular}


Table 2. Cont.

\begin{tabular}{|c|c|c|c|c|c|}
\hline Oregano Species & Extract & Compounds & Plant Part & Antioxidant Assay & Reference \\
\hline Origanum microphyllum & Aqueous & $\begin{array}{l}p \text {-Hydroxybenzoic, protocatechuic, syringic and } \\
\text { caffeic acids, naringenin }\end{array}$ & $\begin{array}{l}\text { Leaves and } \\
\text { flowers }\end{array}$ & TPC, FRAP & [26] \\
\hline \multirow{4}{*}{ Origanum vulgare } & Methanol & Rosmarinic acid & Leaves & TPC, ORAC & [78] \\
\hline & Methanol & Rosmarinic acid and (-)-epicatechin & Leaves & DPPH; ABTS, FRAP & [10] \\
\hline & $\begin{array}{l}\text { Water, methanol, ethyl } \\
\text { acetate, hexane }\end{array}$ & Rosmarinic, caffeic, chicoric and $p$-coumaric acids & Leaves & $\begin{array}{l}\text { TPC, DPPH, TAC, RP, } \\
\text { superoxide }\end{array}$ & [32] \\
\hline & Methanol & Rosmarinic acid, eriodictyol, naringenin & Leaves & TPC, ORAC & [30] \\
\hline \multirow[t]{2}{*}{ Origanum vulgare } & Methanol & $\begin{array}{l}\text { Rosmarinic and caffeic acids, luteolin-7-O-glucoside, } \\
\text { apigenin-7-O-glucoside }\end{array}$ & Not specified & TPC, FRAP & [79] \\
\hline & Aqueous & Eriodictyol, apigenin, caffeic acid, kaempferol & Not specified & TPC, DPPH & [80] \\
\hline Thymbra capitata & Ethyl acetate, ethanol & $\begin{array}{l}\text { Ethyl acetate: taxifolin di-O-glucoside, thymusin. } \\
\text { Ethanol: taxifolin di-O-glucoside, rosmarinic acid }\end{array}$ & Aerial parts & TPC, superoxide & [81] \\
\hline
\end{tabular}




\subsection{Anti-Inflammatory Properties of FL and PA from Oregano}

Inflammation is a response of the organism to detect and destroy harmful agents [82]. During inflammation, the synthesis of pro-inflammatory mediators is activated. Some of these mediators are nitric oxide (NO), reactive oxygen species (ROS), cytokines and prostaglandins (PGs), as well as enzymes such as inducible nitric oxide synthase (iNOS) and cyclooxygenases (COXs) [83]. When the inflammatory response is not well regulated an overproduction of these mediators is triggered causing pathological processes associated to diseases namely, arthritis, atherosclerosis and cancer, among others $[84,85]$. Therefore, the inhibition of the pro-inflammatory mediators mentioned is an important objective for the treatment of inflammation-related diseases.

It has been suggested that phenolic compounds from oregano, such as flavonoids and phenolic acids, might exert anti-inflammatory properties (Table 3) [86-88]. In this regard, Mueller et al. [89] evaluated the anti-inflammatory activity of Origanum onites and O. majorana hydrophilic extracts on lipopolysaccharide (LPS)-stimulated RAW 264.7 macrophage cells. Pre-treatment of the cells with O. onites extracts at $500 \mu \mathrm{g} / \mathrm{mL}$ and $200 \mu \mathrm{g} / \mathrm{mL}$ reduced $19 \%$ and $49 \%$ the secretion of the pro-inflammatory cytokine IL-6, respectively, while the expression of iNOS was completely inhibited. Similarly, when macrophages were pre-treated with the extracts from O. majorana at $500 \mu \mathrm{g} / \mathrm{mL}$ and $200 \mu \mathrm{g} / \mathrm{mL}$ the levels of IL-6 were reduced $20 \%$ and $17 \%$, respectively, while the iNOS expression was diminished $66 \%$. Even though Mueller et al. [89] did not identify the compounds in the O. onites and O. majorana extracts, they mention that diosmetin, apigenin, luteolin and rosmarinic acid are the compounds to most likely be present in the hydrophilic extracts, so these molecules might be responsible for the activity of oregano extracts. On the other hand, aqueous infusion of $O$. vulgare was evaluated by Kogiannou et al. [26] in order to know their effect on IL-8 secretion, a pro-inflammatory and cancer promoting cytokine, in the cancerous cell lines HT-29 and PC3. When cells were treated with the $O$. vulgare infusion powder $(0.2 \mu \mathrm{g}$ powder $/ \mu \mathrm{L}$ of medium $)$ and stimulated with TNF- $\alpha$, the IL-8 concentration on the medium was significantly reduced in both HT-29 and PC 3 cells. The phenolic acid and flavonoid profile of the infusion from $O$. vulgare was also determined. The authors attributed to caffeic acid present in the infusion part of the anti-IL-8 activity of oregano.

Recently, it has been demonstrated that extracts from the oregano species Lippia graveolens, L. palmeri and Hedeoma patens, containing quercetin, luteolin and scutellarein derivatives and salvianolic and neochlorogenic acids, showed anti-inflammatory activity by lowering ROS and NO production in LPS-induced inflammation in lipopolysaccharide (LPS)-stimulated RAW 264.7 macrophage cells [4].

For a better understanding on how phenolic compounds exert their anti-inflammatory activity we recommend to review the papers by Ambriz-Pérez et al. [58] and Leyva-López et al. [90].

Table 3. A summary of the anti-inflammatory properties of flavonoids and phenolic acids of different oregano species.

\begin{tabular}{lll}
\hline Oregano Species & \multicolumn{1}{c}{ Compounds } & \multicolumn{1}{c}{ Effect } \\
\hline $\begin{array}{l}\text { Eryngium } \\
\text { foetidum }\end{array}$ & Kaempferol, chlorogenic acid, caffeic acid & $\begin{array}{l}\text { Reduction of NO and ROS production and } \\
\text { inhibition of the protein levels and gene } \\
\text { expression of IL-6, TNF- } \alpha, \text { iNOS and } \\
\text { COX-2 in LPS-stimulated RAW 264.7 } \\
\text { murine macrophages }\end{array}$ \\
\hline Hedeoma patens & $\begin{array}{l}\text { Neochlorogenic acid, } \\
\text { Luteolin-7-O-glucuronide, } \\
\text { scutellarein-7-O-hexoside, salvianolic acid A }\end{array}$ & $\begin{array}{l}\text { Reduction of the levels of NO and ROS } \\
\text { produced in murine macrophage cells }\end{array}$ \\
\hline Lippia graveolens & $\begin{array}{l}\text { Quercetin-O-hexoside, } \\
\text { scutellarein-7-O-hexoside, phloridzin, } \\
\text { trihydroxy-methoxyflavone derivative, } \\
\text { 6-O-methylscutellarein }\end{array}$ & $\begin{array}{l}\text { Inhibition of the NO and ROS production } \\
\text { in LPS-stimulated murine macrophage cells }\end{array}$ \\
\hline
\end{tabular}


Table 3. Cont.

\begin{tabular}{llll}
\hline Oregano Species & \multicolumn{1}{c}{ Compounds } & \multicolumn{1}{c}{ Effect } & Reference \\
\hline & $\begin{array}{l}\text { Quercetin-O-hexoside, } \\
\text { luteolin-7-O-glucuronide-3'-O-glucoside, } \\
\text { scutellarein-7-O-hexoside, } \\
\text { trihydroxy-methoxyflavone derivative, } \\
\text { 6-O-methylscutellarein }\end{array}$ & $\begin{array}{l}\text { Decrease of the levels of NO and ROS } \\
\text { produced in murine macrophage cells }\end{array}$ & {$[4]$} \\
\hline Origanum vulgare & Caffeic acid & $\begin{array}{l}\text { Diminution of IL-8 secretion in HT-29 and } \\
\text { PC3 cells }\end{array}$ & [26] \\
\hline
\end{tabular}

\subsection{Anti-Cancer Properties of FL and PA from Oregano}

Cancer is described as "a group of diseases characterized by unregulated cell growth and the invasion and spread of cells from the site of origin, or primary site, to other sites in the body" [91]. Several factors are involved in the onset of cancer such as age, alcohol, cancer-causing substances, diet, hormones, obesity, radiation, tobacco, etc.; and they may play a direct or indirect role in the development and progressions of different types of cancers. Carcinogenesis includes five known steps: initiation, promotion, progression, invasion and metastasis. The National Cancer Institute [92] states that in vitro and in vivo studies have shown that the increased presence of antioxidants prevents free radical damage that has been associated with cancer development. Plant foods are the most significance source of natural antioxidants; from which, flavonoids and phenolic acids have attracted the most attention as potential therapeutic agents against cancer. Shukla and Gupta [93] summarized that the potential anticancer properties of FL and PA as demonstrated by laboratory studies are due to different mechanisms of action, including antioxidation, induction of detoxification enzymes and inhibition of bioactivation enzymes, estrogenic and anti-estrogenic activity, antiproliferation, cell cycle arrest and apoptosis, promotion of differentiation, regulation of host immune function and inhibition of angiogenesis and metastasis. Several of the wide variety of FL and PA that have been identified in species classified as oregano have been reported with anti-cancer properties (Table 4). Thus, research has focused on the use of oregano FL and PA as potential anti-cancer therapy.

In this subject, the ethanolic extracts from Origanum compactum showed cytotoxic activity against human breast cancer cells (MCF7) and this effect was partially attributed to its FL content [94]. Calderón et al. [95] used the methanolic extracts of Lippia cardiostegia had cytotoxic activity at values from GI50 of 5.5, 5.2 and 7.5 ( $\mu \mathrm{g} / \mathrm{mL})$ over breast (MCF-7), lung (H-460) and central nervous system (SF-268) human cancer cell lines. Methanolic extract from Origanum compactum also exhibited cytotoxic activity against MCF-7 cells, with IC50 values from $382 \mu \mathrm{g} / \mathrm{mL}$ to $374 \mu \mathrm{g} / \mathrm{mL}$ [96]. Hesperetin isolated from Origanum majorana has shown better antiproliferative activity than 5-fluoroacil against Rattus norvegicus brain glioma (C6) and HeLa cells [97]. The FL and PA of hydroalcoholic extracts from Origanum vulgare L. subsp. viridulum showed antiproliferative activity, with $44 \%$ of inhibition of cell proliferation against human breast cancer cells (MFC-7), around $64 \%$ of inhibition against hepatic cancer cells (HepG2) and around $40 \%$ of inhibition of colorectal cancer (LoVo) cells. It is important to mention that Origanum vulgare extracts seemed to exhibit a selective antiproliferative activity against HepG2 [98].

Savini et al. [99] evaluated the ethanolic extracts from Origanum vulgare on cell proliferation and cell death in colon adenocarcinoma (Caco-2) cells; finding that at a concentration of $300 \mu \mathrm{g} / \mathrm{mL}$ oregano extract cell viability of decreased approximately $30 \%$ after $24 \mathrm{~h}$; however, at a concentration of $500 \mu \mathrm{g} / \mathrm{mL}$ death time-dependently occurred. They also suggested that the mix of phenolic compounds found in O. vulgare extracts is more effective than individual phenolics, indicating a synergistic effect between compounds. Moreover, Nile et al. [100] suggested that the high cytotoxicity of Origanum vulgare extracts against breast cancer cells (MFC-7) is related to its high phenolic content

Likewise, García-Pérez et al. [57] evaluated different extracts from Poliomintha glabrescens for cytotoxic activity in colon cancer cells HT-29. The evaluated samples showed inhibition of the 
proliferation of HT-29 cell line, which was partially attributed to the luteolin and apigenin content in Poliomintha glabrescens.

According to all of these studies, the phenolic extracts and isolated flavonoids and phenolic acids of species classified as oregano are a promising source for the development of new drugs in the treatment of cancer, nevertheless more research is necessary to understand in detail the mechanisms of action of these compounds as well as their effects on in vivo models and the possible side effects that could occur their administration.

Table 4. A summary of the anti-cancer properties of flavonoids and phenolic acids of different oregano species.

\begin{tabular}{|c|c|c|c|}
\hline Oregano Species & Anti-Cancer Activity & Effect & Reference \\
\hline Origanum dictmnus & Cytotoxic & $\begin{array}{l}\text { Activity against human bronchial epidermoid carcinoma } \\
\text { (NSCLC-N6) and murine leukemia (P388) cells line. }\end{array}$ & [101] \\
\hline \multirow{2}{*}{ Origanum compactum } & Cytotoxic & Activity against human breast cancer cells (MCF-7) & [94] \\
\hline & Antiproliferative & Inhibit human breast cancer (MCF-7) cell proliferation. & [96] \\
\hline Origanum syriacum & Antiproliferative & $\begin{array}{l}\text { Reduction in the proliferation of human breast cancer } \\
\text { cells (MFC-7). }\end{array}$ & [102] \\
\hline \multirow[t]{2}{*}{ Origanum vulgare } & Antiproliferative & $\begin{array}{l}\text { Reduction in the proliferation of human breast cancer } \\
\text { (MFC-7), colorectal cancer (LoVo), cervical epithelial } \\
\text { carcinoma (HeLa) cells and selective antiproliferative } \\
\text { activity on hepatic cancer cells (HepG2). }\end{array}$ & {$[32,98,102]$} \\
\hline & Cytotoxic & $\begin{array}{l}\text { Showed signs of cells death on cervical epithelial } \\
\text { carcinoma (HeLa) cell line and cytotoxicity for breast } \\
\text { cancer and colon adenocarcinoma (Caco-2) cells. }\end{array}$ & {$[98-100,103]$} \\
\hline $\begin{array}{l}\text { Lippia cardiostegia } \\
\text { Benth }\end{array}$ & Cytotoxic & $\begin{array}{l}\text { Activity against breast (MCF-7), lung (H-460) and } \\
\text { central nervous system (SF-268) human cancer cell lines. }\end{array}$ & [95] \\
\hline \multirow[t]{2}{*}{ Origanum marjorana } & Antiproliferative & $\begin{array}{l}\text { Inhibit Rattus norvegicus brain glioma (C6) and cervical } \\
\text { epithelial carcinoma (HeLa) cell proliferation. }\end{array}$ & [97] \\
\hline & Cytotoxic & Activity against fibrosarcoma (HT-1080) cell line. & [98] \\
\hline Origanum acutidens & Antiproliferative & $\begin{array}{l}\text { Inhibit cervical epithelial carcinoma (HeLa) cell } \\
\text { proliferation. }\end{array}$ & [32] \\
\hline $\begin{array}{l}\text { Poliomintha } \\
\text { glabrescens Gray }\end{array}$ & Cytotoxic & Activity against human colon cancer cells (HT-29). & [57] \\
\hline
\end{tabular}

\section{Enhancement of Flavonoid and Phenolic Acids Content in Oregano Species}

As previously shown, oregano species are an important source of flavonoids and phenolic acids, which have been of special interest because of their potential use as antioxidants, anti-inflammatory and anti-cancer agents [4]. As a consequence, the enhancement of FL and PA in oregano species is desired. Consequently, research has shown that flavonoids and phenolic acids in plants can be enhanced by several methods; however, research regarding enhancement of FL and PA content in oregano is scarce [104-108]; nonetheless there are few studies on enhancement of FL and PA from Lamiaceae herbs, like Ocimum basilicum, that can provide information for further research in plants known as oregano. Among the most studied are the agronomic approaches and through the use of plant elicitors [109]. The main agricultural method focuses on the manipulation of FL and PA content by the manipulation of nutrient (such as application of nitrogen fertilizers) and altering irrigation strategies. On the other hand, plant elicitors are compounds that can induce plant defense reactions that could result in the production of defense secondary metabolites such as FL and PA [108].

\subsection{Nutrient Manipulation}

Few studies have focused on the effect of nutrient manipulation on the enhancement of flavonoid and phenolic acid content in oregano species. Briefly, boron toxicity was shown to increase phenolic content and anthocyanins in Ocimum basilicum, which is suggested to be a plant strategy to mitigate the negative effects of boron within the cells [110]. A couple of studies have also researched the effects 
of nitrogen manipulation on the phenolic content and antioxidant capacity in Ocimum basilicum and have shown that the levels of phenolics such as rosmarinic and caffeic acid can be enhanced as a result of nitrogen treatment [111,112]. Moreover, the total content of rosmarinic acid of Origanum vulgare can be increased when cultivated under manipulation of proline content [104]. However, caution is needed since these strategies can hinder plant growth.

\subsection{Light Quality}

FL and PA are secondary metabolites that are metabolized as a response to UV stress in order to avoid oxidative stress on plants. In this regard, some studies have addressed this issue by studying the effect of light quality on FL and PA content. However, research regarding the effect of light stress on FL and PA content in oregano is scarce. For instance, Shiga et al. [113] showed that the rosmarinic acid content and antioxidant capacity of Ocimum basilicum L. were increased as a result of white light irradiation. Another study in Ocimum basilicum L. by Ghasemzadeh et al. [114] reported that UV-B radiation $\left(3.60 \mathrm{~W} / \mathrm{m}^{2}\right)$ improved the total phenolic and flavonoid content as well as the content of gallic acid, cinnamic acid, ferulic acid, quercetin, catechin, kaempferol, rutin and luteolin. UV treatment can also increase the content of rosmarinic acid in Origanum vulgare [106]. Additionally, UV-B treatment increased the activity of the enzyme chalcone synthase (EC: 2.3.1.74), which is a key enzyme in the phenylpropanoid metabolism, catalyzing the conversion of p-coumaroyl-CoA and malonyl-CoA to naringenin chalcone, which is a precursor of flavonoids [115].

\subsection{Plant Elicitors}

\subsubsection{Chitosan}

Chitosan is a biopolymer produced the deacetylation of chitin. And has been extensively studied as a plant elicitor in several crops [116]. Some reports have shown the use of chitosan as a FL and PA enhancer in oregano species. For instance, the content of rosmarinic acid in Ocimum basilicum L. increased after chitosan treatment [117]. Similarly, Yin et al. [108] applied chitosan oligosaccharides in Origanum vulgare ssp. hirtum, which resulted in increased content of lithospermic acid B and apigenin-6,8-diglucoside. Moreover, a combination of application of chitosan on Ocimum basilicum and reduced irrigation increased the total phenolic content and antioxidant activity [118]. Overall, these studies concluded that chitosan concentration had an impact on LF and PA stimulation.

\subsubsection{Plant Growth Regulators}

Growth and development in plants is regulated by endogenous phytohormones that play key roles on their metabolism. Additionally, these molecules can be used as potent elicitors. Among the most commonly used growth regulators are methyl jasmonate, jasmonic acid, spermine and arachidonic acid. In this regard, Koca and Karaman [119] showed that the application of a combination of methyl jasmonate and spermine enhanced the rosmarinic acid content in Ocimum basilicum L. Similarly, a study by Złotek et al. [120] in purple Ocimum basilicum showed an increased content of benzoic acid and rosmarinic acid after application of arachidonic and jasmonic acid. Malekpoor et al. [121] also showed an increased total phenolic content and antioxidant activity in Ocimum basilicum L. after treatment with jasmonic acid. Moreover, Kim et al. [122] showed that application of methyl jasmonate in Ocimum basilicum L. enhanced the rosmarinic and caffeic acid as well as the antioxidant activity of the samples. Additionally, acetyl salicylic acid in combination with fish protein hydrolyzate has been shown to stimulate the phenylpropanoid metabolism, which results in higher antioxidant activity [107].

Interestingly, even though enhancement FL and PA content is desired in oregano species due to their proposed human health effects, high concentrations of these compounds have shown a reduced plant growth and reproduction [109]. It is important to mention that even though the aim of this study was not to summarize flavonoid and phenolic acids enhancement methods, we consider of interest 
to recommend the studies by Malerba and Cerana [116], García-Mier et al. [109], Pichyangkura and Chadchawan [123] and Trivellini et al. [124].

\section{Conclusions}

In conclusion, due to the wide variety of herbs regarded as oregano, there is a complex mixture of flavonoids and phenolic acids that can be found throughout them, from which flavones are the main constituents. These compounds have been of particular interest for their potential bioactive properties and promising role as alternative treatment in several illnesses. Here we have summarized the most recent studies focusing on the characterization studies of oregano FL and PA as well as their antioxidant, anti-inflammatory and anti-cancer properties. Interestingly, most of the studies are based on in vitro approaches, limiting its extrapolation to human health. Hence, further in vivo research is needed to understand the bioavailability, pharmacokinetics and mechanism of action of oregano FL and PA as agents in human health improvement.

Acknowledgments: This work was financially supported by the Mexican Council for Science and Technology (CONACyT) (Proyecto Ciencia Básica 25416). Erick P. Gutiérrez-Grijalva would like to acknowledge the doctoral scholarship (Grant \#391880) received from the CONACyT.

Author Contributions: Erick P. Gutiérrez-Grijalva initiated this review in partial fulfillment of his experimental education under the supervision of J. Basilio Heredia; both of them contributed with the edition of this manuscript. Nayely Leyva-López, Manuel A. Picos-Salas, Marilyn S. Criollo-Mendoza and Gabriela Vazquez-Olivo contributed to its writing.

Conflicts of Interest: The authors declare no conflict of interest.

\section{Abbreviations}

$\begin{array}{ll}\text { FL } & \text { Flavonoids } \\ \text { PA } & \text { Phenolic acids } \\ \text { BHT } & \text { Butylated hydroxytoluene } \\ \text { HAT } & \text { Hydrogen atom transfer } \\ \text { ET } & \text { Electron transfer } \\ \text { ORAC } & \text { Oxygen radical absorbance assay } \\ \text { DPPH } & 1,1^{\prime} \text {-diphenyl-2-picrylhydrazyl radical } \\ \text { ABTS } & 2,2^{\prime} \text {-azino-bis(3-ethylbenzothiazoline-6-sulphonic acid) } \\ \text { FRAP } & \text { Ferric reducing-antioxidant power assay } \\ \text { CUPRAC } & \text { Cupric ion reducing antioxidant capacity } \\ \text { TAC } & \text { Total antioxidant capacity } \\ \text { TPC } & \text { Total phenolic content } \\ \text { DW } & \text { Dried weight } \\ \text { DWE } & \text { Dried weight extract } \\ \text { NO } & \text { Nitric oxide } \\ \text { ROS } & \text { Reactive oxygen species } \\ \text { IL-6 } & \text { Interleukin } 6 \\ \text { IL-8 } & \text { Interleukin } 8 \\ \text { IL-10 } & \text { Interleukin 10 } \\ \text { TNF- } \alpha & \text { Tumor necrosis factor alpha } \\ \text { COX-2 } & \text { Cyclooxygenase-2 } \\ \text { LPS } & \text { Lipopolysaccharide } \\ \text { iNOS } & \text { Nitric oxide synthase } \\ \text { COXs } & \text { Cyclooxygenases } \\ \end{array}$




\section{References}

1. Calpouzos, L. Botanical aspects of oregano. Econ. Bot. 1954, 8, 222-223. [CrossRef]

2. Franz, C.; Novak, J. Sources of essential oils. In Handbook of Essential Oils; CRC Press: Boca Raton, FL, USA, 2009; pp. 39-81.

3. Pascual, M.E.; Slowing, K.; Carretero, E.; Sánchez Mata, D.; Villar, A. Lippia: Traditional uses, chemistry and pharmacology: A review. J. Ethnopharmacol. 2001, 76, 201-214. [CrossRef]

4. Leyva-López, N.; Nair, V.; Bang, W.Y.; Cisneros-Zevallos, L.; Heredia, J.B. Protective role of terpenes and polyphenols from three species of oregano (Lippia graveolens, Lippia palmeri and Hedeoma patens) on the suppression of lipopolysaccharide-induced inflammation in RAW 264.7 macrophage cells. J. Ethnopharmacol. 2016, 187, 302-312. [CrossRef] [PubMed]

5. Lattanzio, V.; Kroon, P.A.; Quideau, S.; Treutter, D. Plant phenolics-Secondary metabolites with diverse functions. In Recent Advances in Polyphenol Research; Daayf, F., Lattanzio, V., Eds.; Blackwell Publishing Ltw: Oxford, UK, 2008; Volume 1.

6. Vermerris, W.; Nicholson, R. The role of phenols in plant defense. In Phenolic Compound Biochemistry; Springer: Dordrecht, The Netherlands, 2006; pp. 211-234.

7. Croteau, R.; Kutchan, T.M.; Lewis, N.G. Natural products (secondary metabolites). In Biochemistry $\mathcal{E}$ Molecular Biology of Plants; Buchanan, B., Gruissem, W., Jones, R., Eds.; American Society of Plants: Rockville, MD, USA, 2015; pp. 1250-1318.

8. Leyva-López, N.; Gutiérrez-Grijalva, E.; Vazquez-Olivo, G.; Heredia, J. Essential oils of oregano: Biological activity beyond their antimicrobial properties. Molecules 2017, 22, 989. [CrossRef] [PubMed]

9. Lin, L.-Z.; Mukhopadhyay, S.; Robbins, R.J.; Harnly, J.M. Identification and quantification of flavonoids of Mexican oregano (Lippia graveolens) by LC-DAD-ESI/MS analysis. J. Food Compos. Anal. 2007, 20, 361-369. [CrossRef] [PubMed]

10. Gonçalves, S.; Moreira, E.; Grosso, C.; Andrade, P.B.; Valentão, P.; Romano, A. Phenolic profile, antioxidant activity and enzyme inhibitory activities of extracts from aromatic plants used in mediterranean diet. J. Food Sci. Technol. 2017, 54, 219-227. [CrossRef] [PubMed]

11. Cartea, M.E.; Francisco, M.; Soengas, P.; Velasco, P. Phenolic compounds in Brassica vegetables. Molecules 2010, 16, 251-280. [CrossRef] [PubMed]

12. Haminiuk, C.W.I.; Maciel, G.M.; Plata-Oviedo, M.S.V.; Peralta, R.M. Phenolic compounds in fruits-An overview. Int. J. Food Sci. Technol. 2012, 47, 2023-2044. [CrossRef]

13. Khoddami, A.; Wilkes, A.M.; Roberts, H.T. Techniques for analysis of plant phenolic compounds. Molecules 2013, 18, 2328-2375. [CrossRef] [PubMed]

14. Vermerris, W.; Nicholson, R. Families of phenolic compounds and means of classification. In Phenolic Compound Biochemistry; Springer: Dordrecht, The Netherlands, 2008; pp. 1-34.

15. Gutiérrez-Grijalva, E.P.; Ambriz-Pére, D.L.; Leyva-López, N.; Castillo-López, R.I.; Heredia, J.B. Review: Dietary phenolic compounds, health benefits and bioaccessibility. Arch. Latinoam. Nutr. 2016, 66, 87-100.

16. Jiang, N.; Doseff, A.; Grotewold, E. Flavones: From biosynthesis to health benefits. Plants 2016, 5, 27. [CrossRef] [PubMed]

17. Singh, M.; Kaur, M.; Silakari, O. Flavones: An important scaffold for medicinal chemistry. Eur. J. Med. Chem. 2014, 84, 206-239. [CrossRef] [PubMed]

18. El-Seedi, H.R.; El-Said, A.M.A.; Khalifa, S.A.M.; Göransson, U.; Bohlin, L.; Borg-Karlson, A.-K.; Verpoorte, R. Biosynthesis, natural sources, dietary intake, pharmacokinetic properties and biological activities of hydroxycinnamic acids. J. Agric. Food Chem. 2012, 60, 10877-10895. [CrossRef] [PubMed]

19. Andrés-Lacueva, C.; Medina-Remon, A.; Llorach, R.; Urpi-Sarda, M.; Khan, N.; Chiva-Blanch, G.; Zamora-Ros, R.; Rotches-Ribalta, M.; Lamuela-Raventos, R.M. Phenolic compounds: Chemistry and occurrence in fruits and vegetables. In Fruit and Vegetable Phytochemicals: Chemistry, Nutritional Value and Stability; Wiley-Blackwell: Ames, IA, USA, 2010; pp. 53-56.

20. Rothwell, J.A.; Perez-Jimenez, J.; Neveu, V.; Medina-Remón, A.; M’Hiri, N.; García-Lobato, P.; Manach, C.; Knox, C.; Eisner, R.; Wishart, D.S.; et al. Phenol-explorer 3.0: A major update of the phenol-explorer database to incorporate data on the effects of food processing on polyphenol content. Database 2013, 2013, bat070. [CrossRef] [PubMed] 
21. Timóteo, P.; Karioti, A.; Leitão, S.G.; Vincieri, F.F.; Bilia, A.R. A validated HPLC method for the analysis of herbal teas from three chemotypes of brazilian Lippia alba. Food Chem. 2015, 175, 366-373. [CrossRef] [PubMed]

22. Barbosa, F.G.; Lima, M.A.S.; Silveira, E.R. Total NMR assignments of new [C7-o-C7"]-biflavones from leaves of the limonene-carvone chemotype of Lippia alba (Mill) N. E. Brown. Magn. Reson. Chem. 2005, 43, 334-338. [CrossRef] [PubMed]

23. Shen, D.; Pan, M.-H.; Wu, Q.-L.; Park, C.-H.; Juliani, H.R.; Ho, C.-T.; Simon, J.E. LC-MS method for the simultaneous quantitation of the anti-inflammatory constituents in oregano (Origanum species). J. Agric. Food Chem. 2010, 58, 7119-7125. [CrossRef] [PubMed]

24. Baâtour, O.; Kaddour, R.; Tarchoun, I.; Nasri, N.; Mahmoudi, H.; Zaghdoudi, M.; Ghaith, H.; Marzouk, B.; Nasri-Ayachi, M.B.; Lachaâl, M. Modification of fatty acid, essential oil and phenolic contents of salt-treated sweet marjoram (Origanum majorana L.) according to developmental stage. J. Food Sci. 2012, 77, C1047-C1054. [CrossRef] [PubMed]

25. Stashenko, E.E.; Martínez, J.R.; Cala, M.P.; Durán, D.C.; Caballero, D. Chromatographic and mass spectrometric characterization of essential oils and extracts from Lippia (Verbenaceae) aromatic plants. J. Sep. Sci. 2013, 36, 192-202. [CrossRef] [PubMed]

26. Kogiannou, D.A.A.; Kalogeropoulos, N.; Kefalas, P.; Polissiou, M.G.; Kaliora, A.C. Herbal infusions; their phenolic profile, antioxidant and anti-inflammatory effects in HT29 and PC3 cells. Food Chem. Toxicol. 2013, 61, 152-159. [CrossRef] [PubMed]

27. Vallverdú-Queralt, A.; Regueiro, J.; Martínez-Huélamo, M.; Rinaldi Alvarenga, J.F.; Leal, L.N.; Lamuela-Raventos, R.M. A comprehensive study on the phenolic profile of widely used culinary herbs and spices: Rosemary, thyme, oregano, cinnamon, cumin and bay. Food Chem. 2014, 154, 299-307. [CrossRef] [PubMed]

28. Hennebelle, T.; Sahpaz, S.; Gressier, B.; Joseph, H.; Bailleul, F. Antioxidant and neurosedative properties of polyphenols and iridoids from Lippia alba. Phytother. Res. 2008, 22, 256-258. [CrossRef] [PubMed]

29. Quirantes-Piné, R.; Funes, L.; Micol, V.; Segura-Carretero, A.; Fernández-Gutiérrez, A. High-performance liquid chromatography with diode array detection coupled to electrospray time-of-flight and ion-trap tandem mass spectrometry to identify phenolic compounds from a lemon verbena extract. J. Chromatogr. A 2009, 1216, 5391-5397. [CrossRef] [PubMed]

30. Bower, A.M.; Hernandez, L.M.R.; Berhow, M.A.; de Mejia, E.G. Bioactive compounds from culinary herbs inhibit a molecular target for type 2 diabetes management, dipeptidyl peptidase iv. J. Agric. Food Chem. 2014, 62, 6147-6158. [CrossRef] [PubMed]

31. Berdowska, I.; Zieliński, B.; Fecka, I.; Kulbacka, J.; Saczko, J.; Gamian, A. Cytotoxic impact of phenolics from Lamiaceae species on human breast cancer cells. Food Chem. 2013, 141, 1313-1321. [CrossRef] [PubMed]

32. Koldaş, S.; Demirtas, I.; Ozen, T.; Demirci, M.A.; Behçet, L. Phytochemical screening, anticancer and antioxidant activities of Origanum vulgare L. ssp. viride (Boiss.) Hayek, a plant of traditional usage. J. Sci. Food Agric. 2015, 95, 786-798. [PubMed]

33. Proestos, C.; Komaitis, M. Analysis of naturally occurring phenolic compounds in aromatic plants by RP-HPLC coupled to diode array detector (DAD) and GC-MS after silylation. Foods 2013, 2, 90-99. [CrossRef] [PubMed]

34. Kaliora, A.C.; Kogiannou, D.A.A.; Kefalas, P.; Papassideri, I.S.; Kalogeropoulos, N. Phenolic profiles and antioxidant and anticarcinogenic activities of greek herbal infusions; balancing delight and chemoprevention? Food Chem. 2014, 142, 233-241. [CrossRef] [PubMed]

35. Pizzale, L.; Bortolomeazzi, R.; Vichi, S.; Überegger, E.; Conte, L.S. Antioxidant activity of sage (Salvia officinalis and $S$ fruticosa) and oregano (Origanum onites and $O$ indercedens) extracts related to their phenolic compound content. J. Sci. Food Agric. 2002, 82, 1645-1651. [CrossRef]

36. Engel, R.; Szabó, K.; Abrankó, L.; Rendes, K.; Füzy, A.; Takács, T. Effect of arbuscular mycorrhizal fungi on the growth and polyphenol profile of marjoram, lemon balm and marigold. J. Agric. Food Chem. 2016, 64, 3733-3742. [CrossRef] [PubMed]

37. Taamalli, A.; Arráez-Román, D.; Abaza, L.; Iswaldi, I.; Fernández-Gutiérrez, A.; Zarrouk, M.; Segura-Carretero, A. LC-MS-based metabolite profiling of methanolic extracts from the medicinal and aromatic species Mentha pulegium and Origanum majorana. Phytochem. Anal. 2015, 26, 320-330. [CrossRef] [PubMed] 
38. Zgórka, G.; Głowniak, K. Variation of free phenolic acids in medicinal plants belonging to the Lamiaceae family. J. Pharm. Biomed. Anal. 2001, 26, 79-87. [CrossRef]

39. Hossain, M.B.; Camphuis, G.; Aguiló-Aguayo, I.; Gangopadhyay, N.; Rai, D.K. Antioxidant activity guided separation of major polyphenols of marjoram (Origanum majorana L.) using flash chromatography and their identification by liquid chromatography coupled with electrospray ionization tandem mass spectrometry. J. Sep. Sci. 2014, 37, 3205-3213. [CrossRef] [PubMed]

40. Kaiser, A.; Carle, R.; Kammerer, D.R. Effects of blanching on polyphenol stability of innovative paste-like parsley (Petroselinum crispum (Mill.) Nym Ex A. W. Hill) and marjoram (Origanum majorana L.) products. Food Chem. 2013, 138, 1648-1656. [CrossRef] [PubMed]

41. Grevsen, K.; Frette, X.C.; Christensen, L.P. Content and composition of volatile terpenes, flavonoids and phenolic acids in greek oregano (Origanum vulgare L. ssp. hirtum) at different development stages during cultivation in cool temperate climate. Eur. J. Hortic. Sci. 2009, 74, 193-203.

42. Tuttolomondo, T.; La Bella, S.; Licata, M.; Virga, G.; Leto, C.; Saija, A.; Trombetta, D.; Tomaino, A.; Speciale, A.; Napoli, E.M.; et al. Biomolecular characterization of wild sicilian oregano: Phytochemical screening of essential oils and extracts and evaluation of their antioxidant activities. Chem. Biodivers. 2013, 10, 411-433. [CrossRef] [PubMed]

43. Vujicic, M.; Nikolic, I.; Kontogianni, V.G.; Saksida, T.; Charisiadis, P.; Orescanin-Dusic, Z.; Blagojevic, D.; Stosic-Grujicic, S.; Tzakos, A.G.; Stojanovic, I. Methanolic extract of Origanum vulgare ameliorates type 1 diabetes through antioxidant, anti-inflammatory and anti-apoptotic activity. Br. J. Nutr. 2015, 113, 770-782. [CrossRef] [PubMed]

44. González, M.D.; Lanzelotti, P.L.; Luis, C.M. Chemical fingerprinting by HPLC-DAD to differentiate certain subspecies of Origanum vulgare L. Food Anal. Methods 2017, 10, 1460-1468. [CrossRef]

45. Hossain, M.B.; Rai, D.K.; Brunton, N.P.; Martin-Diana, A.B.; Barry-Ryan, C. Characterization of phenolic composition in Lamiaceae spices by LC-ESI-MS/MS. J. Agric. Food Chem. 2010, 58, 10576-10581. [CrossRef] [PubMed]

46. Zheng, W.; Wang, S.Y. Antioxidant activity and phenolic compounds in selected herbs. J. Agric. Food Chem. 2001, 49, 5165-5170. [CrossRef] [PubMed]

47. Cheynier, V.; Comte, G.; Davies, K.M.; Lattanzio, V.; Martens, S. Plant phenolics: Recent advances on their biosynthesis, genetics and ecophysiology. Plant Physiol. Biochem. 2013, 72, 1-20. [CrossRef] [PubMed]

48. Alam, M.A.; Subhan, N.; Hossain, H.; Hossain, M.; Reza, H.M.; Rahman, M.M.; Ullah, M.O. Hydroxycinnamic acid derivatives: A potential class of natural compounds for the management of lipid metabolism and obesity. Nutr. Metab. 2016, 13, 27. [CrossRef] [PubMed]

49. Abramovič, H. Chapter 93-Antioxidant properties of hydroxycinnamic acid derivatives: A focus on biochemistry, physicochemical parameters, reactive species and biomolecular interactions a2-Preedy, victor r. In Coffee in Health and Disease Prevention; Academic Press: San Diego, CA, USA, 2015; pp. 843-852.

50. Kumar, S.; Pandey, A.K. Chemistry and biological activities of flavonoids: An overview. Sci. World J. 2013, 2013, 162750. [CrossRef] [PubMed]

51. Ferreyra, M.L.F.; Rius, S.P.; Casati, P. Flavonoids: Biosynthesis, biological functions and biotechnological applications. Front. Plant Sci. 2012, 3, 222.

52. Samanta, A.; Das, G.; Das, S.K. Roles of flavonoids in plants. Carbon 2011, 100, 6.

53. Mierziak, J.; Kostyn, K.; Kulma, A. Flavonoids as important molecules of plant interactions with the environment. Molecules 2014, 19, 16240-16265. [CrossRef] [PubMed]

54. Link, A.; Balaguer, F; Goel, A. Cancer chemoprevention by dietary polyphenols: Promising role for epigenetics. Biochem. Pharmacol. 2010, 80, 1771-1792. [CrossRef] [PubMed]

55. Vauzour, D.; Rodriguez-Mateos, A.; Corona, G.; Oruna-Concha, M.J.; Spencer, J.P.E. Polyphenols and human health: Prevention of disease and mechanisms of action. Nutrients 2010, 2, 1106-1131. [CrossRef] [PubMed]

56. Embuscado, M.E. Spices and herbs: Natural sources of antioxidants-A mini review. J. Funct. Foods 2015, 18, 811-819. [CrossRef]

57. García-Pérez, E.; Noratto, G.D.; García-Lara, S.; Gutiérrez-Uribe, J.A.; Mertens-Talcott, S.U. Micropropagation effect on the anti-carcinogenic activitiy of polyphenolics from mexican oregano (Poliomintha glabrescens Gray) in human colon cancer cells HT-29. Plant Foods Hum. Nutr. 2013, 68, 155-162. [CrossRef] [PubMed]

58. Ambriz-Pérez, D.L.; Leyva-López, N.; Gutierrez-Grijalva, E.P.; Heredia, J.B. Phenolic compounds: Natural alternative in inflammation treatment. A review. Cogent Food Agric. 2016, 2, 1131412. 
59. Xiao, J.; Kai, G.; Yamamoto, K.; Chen, X. Advance in dietary polyphenols as $\alpha$-glucosidases inhibitors: A review on structure-activity relationship aspect. Crit. Rev. Food Sci. Nutr. 2013, 53, 818-836. [CrossRef] [PubMed]

60. Xiao, J.; Ni, X.; Kai, G.; Chen, X. A review on structure-activity relationship of dietary polyphenols inhibiting $\alpha$-amylase. Crit. Rev. Food Sci. Nutr. 2013, 53, 497-506. [CrossRef] [PubMed]

61. Chirumbolo, S. Anticancer properties of the flavone wogonin. Toxicology 2013, 314, 60-64. [CrossRef] [PubMed]

62. Ganai, S.A. Plant-derived flavone apigenin: The small-molecule with promising activity against therapeutically resistant prostate cancer. Biomed. Pharmacother. 2017, 85, 47-56. [CrossRef] [PubMed]

63. Li-Weber, M. New therapeutic aspects of flavones: The anticancer properties of Scutellaria and its main active constituents wogonin, baicalein and baicalin. Cancer Treat. Rev. 2009, 35, 57-68. [CrossRef] [PubMed]

64. Menezes, R.; Rodriguez-Mateos, A.; Kaltsatou, A.; González-Sarrías, A.; Greyling, A.; Giannaki, C.; Andres-Lacueva, C.; Milenkovic, D.; Gibney, R.E.; Dumont, J.; et al. Impact of flavonols on cardiometabolic biomarkers: A meta-analysis of randomized controlled human trials to explore the role of inter-individual variability. Nutrients 2017, 9, 117. [CrossRef] [PubMed]

65. Petersen, M.; Simmonds, M.S.J. Rosmarinic acid. Phytochemistry 2003, 62, 121-125. [CrossRef]

66. Taofiq, O.; González-Paramás, A.; Barreiro, M.; Ferreira, I. Hydroxycinnamic acids and their derivatives: Cosmeceutical significance, challenges and future perspectives, a review. Molecules 2017, 22, 281. [CrossRef] [PubMed]

67. Apak, R.; Gorinstein, S.; Böhm, V.; Schaich, K.M.; Özyürek, M.; Güçlü, K. Methods of measurement and evaluation of natural antioxidant capacity/activity (IUPAC technical report). Pure Appl. Chem. 2013, 85, 957-998. [CrossRef]

68. Apak, R.; Özyürek, M.; Güçlü, K.; Çapanoğlu, E. Antioxidant activity/capacity measurement. 2. Hydrogen atom transfer (HAT)-based, mixed-mode (electron transfer (ET)/HAT) and lipid peroxidation assays. J. Agric. Food Chem. 2016, 64, 1028-1045. [CrossRef] [PubMed]

69. Bhatt, P.; Joseph, G.S.; Negi, P.S.; Varadaraj, M.C. Chemical composition and nutraceutical potential of indian borage (Plectranthus amboinicus) stem extract. J. Chem. 2013, 2013, 320329. [CrossRef]

70. Singh, S.; Singh, D.R.; Banu, S.; Salim, K.M. Determination of bioactives and antioxidant activity in Eryngium foetidum L.: A traditional culinary and medicinal herb. Proc. Nat. Acad. Sci. India Sect. B Biol. Sci. 2013, 83, 453-460. [CrossRef]

71. Martínez-Rocha, A.; Puga, R.; Hernández-Sandoval, L.; Loarca-Piña, G.; Mendoza, S. Antioxidant and antimutagenic activities of Mexican oregano (Lippia graveolens Kunth). Plant Foods Hum. Nutr. 2008, 63, 1-5. [CrossRef] [PubMed]

72. Lagouri, V.; Alexandri, G. Antioxidant properties of greek O. dictamnus and R. officinalis methanol and aqueous extracts-HPLC determination of phenolic acids. Int. J. Food Prop. 2013, 16, 549-562. [CrossRef]

73. Béjaoui, A.; Boulila, A.; Sanaa, A.; Boussaid, M.; Fernandez, X. Antioxidant activity and $\alpha$-amylase inhibitory effect of polyphenolic-rich extract from Origanum glandulosum desf. J. Food Biochem. 2017, 41, e12271-n/a. [CrossRef]

74. Magnani, C.; Isaac, V.L.B.; Correa, M.A.; Salgado, H.R.N. Caffeic acid: A review of its potential use in medications and cosmetics. Anal. Methods 2014, 6, 3203-3210. [CrossRef]

75. Çelik, S.E.; Tufan, A.N.; Bekdeşer, B.; Özyürek, M.; Güçlü, K.; Apak, R. Identification and determination of phenolics in Lamiaceae species by UPLC-DAD-ESI-MS/MS. J. Chromatogr. Sci. 2017, 55, 291-300. [CrossRef] [PubMed]

76. Elansary, H.O.; Mahmoud, E.A. Egyptian herbal tea infusions' antioxidants and their antiproliferative and cytotoxic activities against cancer cells. Nat. Prod. Res. 2015, 29, 474-479. [CrossRef] [PubMed]

77. Vallverdú-Queralt, A.; Regueiro, J.; Alvarenga, J.F.R.; Martinez-Huelamo, M.; Leal, L.N.; Lamuela-Raventos, R.M. Characterization of the phenolic and antioxidant profiles of selected culinary herbs and spices: Caraway, turmeric, dill, marjoram and nutmeg. Food Sc. Technol. (Campinas) 2015, 35, 189-195. [CrossRef]

78. Yan, F.; Azizi, A.; Janke, S.; Schwarz, M.; Zeller, S.; Honermeier, B. Antioxidant capacity variation in the oregano (Origanum vulgare L.) collection of the German National Genebank. Ind. Crop. Prod. 2016, 92, $19-25$. [CrossRef] 
79. Hossain, M.B.; Barry-Ryan, C.; Martin-Diana, A.B.; Brunton, N.P. Optimisation of accelerated solvent extraction of antioxidant compounds from rosemary (Rosmarinus officinalis L.), marjoram (Origanum majorana L.) and oregano (Origanum vulgare L.) using response surface methodology. Food Chem. 2011, 126, 339-346. [CrossRef]

80. Balkan, B.; Balkan, S.; Aydogdu, H.; Guler, N.; Ersoy, H.; Askin, B. Evaluation of antioxidant activities and antifungal activity of different plants species against pink mold rot-causing Trichothecium roseum. Arab. J. Sci. Eng. 2017, 42, 2279-2289. [CrossRef]

81. Saija, A.; Speciale, A.; Trombetta, D.; Leto, C.; Tuttolomondo, T.; La Bella, S.; Licata, M.; Virga, G.; Bonsangue, G.; Gennaro, M.C.; et al. Phytochemical, ecological and antioxidant evaluation of wild sicilian thyme: Thymbra capitata (L.) cav. Chem. Biodivers. 2016, 13, 1641-1655. [CrossRef] [PubMed]

82. Medzhitov, R. Origin and physiological roles of inflammation. Nature 2008, 454, 428-435. [CrossRef] [PubMed]

83. Kumar, V.; Abbas, A.K.; Aster, J.C. Robbins Basic Pathology E-Book; Elsevier Health Sciences: Amsterdam, The Netherlands, 2017.

84. Hansson, G.K. Inflammation, atherosclerosis and coronary artery disease. N. Engl. J. Med. 2005, 352, 1685-1695. [CrossRef] [PubMed]

85. Trinchieri, G. Cancer and inflammation: An old intuition with rapidly evolving new concepts. Annu. Rev. Immunol. 2012, 30, 677-706. [CrossRef] [PubMed]

86. Chen, Y.-S.; Yu, H.-M.; Shie, J.-J.; Cheng, T.-J.R.; Wu, C.-Y.; Fang, J.-M.; Wong, C.-H. Chemical constituents of Plectranthus amboinicus and the synthetic analogs possessing anti-inflammatory activity. Bioorgan. Med. Chem. 2014, 22, 1766-1772. [CrossRef] [PubMed]

87. Jungbauer, A.; Medjakovic, S. Anti-inflammatory properties of culinary herbs and spices that ameliorate the effects of metabolic syndrome. Maturitas 2012, 71, 227-239. [CrossRef] [PubMed]

88. Mekhora, C.; Muangnoi, C.; Chingsuwanrote, P.; Dawilai, S.; Svasti, S.; Chasri, K.; Tuntipopipat, S. Eryngium foetidum suppresses inflammatory mediators produced by macrophages. Asian Pac. J. Cancer Prev. 2012, 13, 653-664. [CrossRef] [PubMed]

89. Mueller, M.; Hobiger, S.; Jungbauer, A. Anti-inflammatory activity of extracts from fruits, herbs and spices. Food Chem. 2010, 122, 987-996. [CrossRef]

90. Leyva-López, N.; Gutierrez-Grijalva, E.; Ambriz-Perez, D.; Heredia, J. Flavonoids as cytokine modulators: A possible therapy for inflammation-related diseases. Int. J. Mol. Sci. 2016, 17, 921. [CrossRef] [PubMed]

91. Pecorino, L. Molecular Biology of Cancer-Mechanisms, Targets and Therapeutics, 3rd ed.; Oxford University Press: Oxford, UK, 2012.

92. National Cancer Institute. Antioxidants and Cancer Prevention. Available online: https://www.cancer.gov/ about-cancer/causes-prevention/risk/diet/antioxidants-fact-sheet (accessed on 3 October 2017).

93. Shukla, S.; Gupta, S. Apigenin and cancer chemoprevention. In Bioactive Foods in Promoting Health: Fruits and Vegetables; Watson, R.R., Preedy, V.R., Eds.; Elsevier Academic Press Inc.: San Diego, CA, USA, 2010; pp. 663-689.

94. El Babili, F.; Bouajila, J.; Souchard, J.P.; Bertrand, C.; Bellvert, F.; Fouraste, I.; Moulis, C.; Valentin, A. Oregano: Chemical analysis and evaluation of its antimalarial, antioxidant and cytotoxic activities. J. Food Sci. 2011, 76, C512-C518. [CrossRef] [PubMed]

95. Calderón, Á.I.; Vázquez, Y.; Solís, P.N.; Caballero-George, C.; Zacchino, S.; Gimenez, A.; Pinzón, R.; Cáceres, A.; Tamayo, G.; Correa, M.; et al. Screening of Latin American plants for cytotoxic activity. Pharm. Biol. 2006, 44, 130-140. [CrossRef]

96. Chaouki, W.; Leger, D.Y.; Eljastimi, J.; Beneytout, J.L.; Hmamouchi, M. Antiproliferative effect of extracts from Aristolochia baetica and Origanum compactum on human breast cancer cell line mcf-7. Pharm. Biol. 2010, 48, 269-274. [CrossRef] [PubMed]

97. Erenler, R.; Sen, O.; Aksit, H.; Demirtas, I.; Yaglioglu, A.S.; Elmastas, M.; Telci, I. Isolation and identification of chemical constituents from Origanum majorana and investigation of antiproliferative and antioxidant activities. J. Sci. Food Agric. 2016, 96, 822-836. [CrossRef] [PubMed]

98. Marrelli, M.; Cristaldi, B.; Menichini, F.; Conforti, F. Inhibitory effects of wild dietary plants on lipid peroxidation and on the proliferation of human cancer cells. Food Chem. Toxicol. 2015, 86, 16-24. [CrossRef] [PubMed] 
99. Savini, I.; Arnone, R.; Catani, M.V.; Avigliano, L. Origanum vulgare induces apoptosis in human colon cancer Caco-2 cells. Nut. Cancer 2009, 61, 381-389. [CrossRef] [PubMed]

100. Nile, S.H.; Nile, A.S.; Keum, Y.S. Total phenolics, antioxidant, antitumor and enzyme inhibitory activity of indian medicinal and aromatic plants extracted with different extraction methods. 3 Biotech 2017, 7, 76. [CrossRef] [PubMed]

101. Chinou, I.; Liolios, C.; Moreau, D.; Roussakis, C. Cytotoxic activity of Origanum dictamnus. Fitoterapia 2007, 78, 342-344. [CrossRef] [PubMed]

102. Al-Kalaldeh, J.Z.; Abu-Dahab, R.; Afifi, F.U. Volatile oil composition and antiproliferative activity of Laurus nobilis, Origanum syriacum, Origanum vulgare and Salvia triloba against human breast adenocarcinoma cells. Nutr. Res. 2010, 30, 271-278. [CrossRef] [PubMed]

103. Berrington, D.; Lall, N. Anticancer activity of certain herbs and spices on the cervical epithelial carcinoma (HeLa) cell line. Evid.-Based Complement. Altern. Med. 2012, 2012, 564927. [CrossRef] [PubMed]

104. Lattanzio, V.; Cardinali, A.; Ruta, C.; Fortunato, I.M.; Lattanzio, V.M.T.; Linsalata, V.; Cicco, N. Relationship of secondary metabolism to growth in oregano (Origanum vulgare L.) shoot cultures under nutritional stress. Environ. Exp. Bot. 2009, 65, 54-62. [CrossRef]

105. Bernstein, N.; Chaimovitch, D.; Dudai, N. Effect of irrigation with secondary treated effluent on essential oil, antioxidant activity and phenolic compounds in oregano and rosemary. Agron. J. 2009, 101, 1-10. [CrossRef]

106. Kwon, Y.-I.; Apostolidis, E.; Kim, Y.-C.; Shetty, K. Over-expression of proline-linked antioxidant pathway and modulation of phenolic metabolites in long life span clonal line of Origanum vulgare in response to ultraviolet radiation. J. Food Biochem. 2009, 33, 649-673. [CrossRef]

107. Andarwulan, N.; Shetty, K. Influence of acetyl salicylic acid in combination with fish protein hydrolysates on hyperhydricity reduction and phenolic synthesis in oregano (Origanum vulgare) tissue cultures. J. Food Biochem. 1999, 23, 619-635. [CrossRef]

108. Yin, H.; Fretté, X.C.; Christensen, L.P.; Grevsen, K. Chitosan oligosaccharides promote the content of polyphenols in Greek oregano (Origanum vulgare ssp. Hirtum). J. Agric. Food Chem. 2012, 60, 136-143. [CrossRef] [PubMed]

109. García-Mier, L.; Guevara-González, R.; Mondragón-Olguín, V.; del Rocío Verduzco-Cuellar, B.; Torres-Pacheco, I. Agriculture and bioactives: Achieving both crop yield and phytochemicals. Int. J. Mol. Sci. 2013, 14, 4203-4222. [CrossRef] [PubMed]

110. Landi, M.; Pardossi, A.; Remorini, D.; Guidi, L. Antioxidant and photosynthetic response of a purple-leaved and a green-leaved cultivar of sweet basil (Ocimum basilicum) to boron excess. Environ. Exp. Bot. 2013, 85, 64-75. [CrossRef]

111. Yépez-Hernández, F.-J.; Ferrera-Cerrato, R.; Alarcón, A.; Delgadillo-Martínez, J.; Mendoza-López, M.R.; García-Barradas, Ó. Fertilización nitrogenada en el crecimiento, contenido de compuestos fenólicos y actividad antioxidante de albahaca. Rev. Fitotec. Mex. 2016, 39, 33-40.

112. Nguyen, P.M.; Niemeyer, E.D. Effects of nitrogen fertilization on the phenolic composition and antioxidant properties of basil (Ocimum basilicum L.). J. Agric. Food Chem. 2008, 56, 8685-8691. [CrossRef] [PubMed]

113. Shiga, T.; Shoji, K.; Shimada, H.; Hashida, S.N.; Goto, F.; Yoshihara, T. Effect of light quality on rosmarinic acid content and antioxidant activity of sweet basil, Ocimum basilicum L. Plant Biotechnol. 2009, 26, 255-259. [CrossRef]

114. Ghasemzadeh, A.; Ashkani, S.; Baghdadi, A.; Pazoki, A.; Jaafar, H.; Rahmat, A. Improvement in flavonoids and phenolic acids production and pharmaceutical quality of sweet basil (Ocimum basilicum L.) by ultraviolet-b irradiation. Molecules 2016, 21, 1203. [CrossRef] [PubMed]

115. Jaganath, I.B.; Crozier, A. Flavonoid biosynthesis. In Plant Metabolism and Biotechnology; Ashihara, H., Crozier, A., Komamine, A., Eds.; John Wiley \& Sons, Ltd.: West Sussex, UK, 2011; pp. 293-320.

116. Malerba, M.; Cerana, R. Chitosan effects on plant systems. Int. J. Mol. Sci. 2016, 17, 996. [CrossRef] [PubMed]

117. Kim, H.-J.; Chen, F.; Wang, X.; Rajapakse, N.C. Effect of chitosan on the biological properties of sweet basil (Ocimum basilicum L.). J. Agric. Food Chem. 2005, 53, 3696-3701. [CrossRef] [PubMed]

118. Ghasemi Pirbalouti, A.; Malekpoor, F.; Salimi, A.; Golparvar, A. Exogenous application of chitosan on biochemical and physiological characteristics, phenolic content and antioxidant activity of two species of basil (Ocimum ciliatum and Ocimum basilicum) under reduced irrigation. Sci. Hortic. 2017, 217, 114-122. [CrossRef] 
119. Koca, N.; Karaman, Ş. The effects of plant growth regulators and L-phenylalanine on phenolic compounds of sweet basil. Food Chem. 2015, 166, 515-521. [CrossRef] [PubMed]

120. Złotek, U.; Szymanowska, U.; Karaś, M.; Świeca, M. Antioxidative and anti-inflammatory potential of phenolics from purple basil (Ocimum basilicum L.) leaves induced by jasmonic, arachidonic and $\beta$-aminobutyric acid elicitation. Int. J. Food Sci. Technol. 2016, 51, 163-170. [CrossRef]

121. Malekpoor, F.; Salimi, A.; Pirbalouti, A.G. Effect of jasmonic acid on total phenolic content and antioxidant activity of extract from the green and purple landraces of sweet basil. Acta Pol. Pharm. 2016, 73, 1229-1234.

122. Kim, H.-J.; Chen, F.; Wang, X.; Rajapakse, N.C. Effect of methyl jasmonate on secondary metabolites of sweet basil (Ocimum basilicum L.). J. Agric. Food Chem. 2006, 54, 2327-2332. [CrossRef] [PubMed]

123. Pichyangkura, R.; Chadchawan, S. Biostimulant activity of chitosan in horticulture. Sci. Hortic. 2015, 196, 49-65. [CrossRef]

124. Trivellini, A.; Lucchesini, M.; Maggini, R.; Mosadegh, H.; Villamarin, T.S.S.; Vernieri, P.; Mensuali-Sodi, A.; Pardossi, A. Lamiaceae phenols as multifaceted compounds: Bioactivity, industrial prospects and role of "positive-stress". Ind. Crop. Prod. 2016, 83, 241-254. [CrossRef]

(C) 2017 by the authors. Licensee MDPI, Basel, Switzerland. This article is an open access article distributed under the terms and conditions of the Creative Commons Attribution (CC BY) license (http://creativecommons.org/licenses/by/4.0/). 